\title{
1. Environmental taxation in the digital world
}

\section{Janet E. Milne*}

\section{INTRODUCTION}

Technological innovation has changed economies from the Industrial Revolution to the new Digital Revolution. Each phase of change generates benefits to society, but also new threats to the environment. Since the midtwentieth century, environmental protection policies have tried to keep pace, innovating to address ever-evolving challenges. Now the emerging digital economy is bringing swift and significant technological advances. Our daily lives are increasingly digital: wireless email, smart phones, online shopping, Uber, Airbnb, telecommuting, streaming, cloud storage, wearable technology and much more. This digital world is the product of a combination of digital data, analytics that use data and connectivity that allows for the exchange of data on digital platforms, often through the Internet. ${ }^{1}$ It has created information highways in the air, revolutionized commerce and transportation, and placed new pressures on the urban landscape.

As one article has noted, "Society's current relationship with the Internet is best described as a blind date." 2 From an environmental perspective, the digital world can reap significant improvements, such as the ability to more effectively integrate renewable energy into the electricity grid and control household energy consumption. But it may also have negative effects, including electronic waste, new demands for energy and accelerated consumerism. ${ }^{3}$ The time is right to anticipate how governments might avoid or minimize adverse impacts of the digital economy, before patterns of behavior have solidified.

This chapter explores the potential for environmental pricing to address the digital world's negative environmental externalities. To provide a concrete context, it delves into selected pockets of digital life: the infrastructure that supports the digital world, in particular spectrum and electricity; online retail that digital technology makes possible, with a focus on packaging and drone delivery; major tech headquarters and new forms 
of transportation that influence the urban landscape; and digital payment systems that change how we pay taxes. Drawing largely on examples from the United States (US), these vignettes provide a partial, introductory glimpse into the implications of the Digital Revolution for the theory and practice of environmental taxes. The pages that follow do not attempt to provide full answers to such a complex, multifaceted topic. They strive instead to highlight the question of whether environmental taxation should innovate alongside the technological changes that increasingly drive economies and society.

\section{THE DIGITAL WORLD'S INFRASTRUCTURE}

At the heart of the digital world lie the information and communications technologies (ICT) that create data processing and connectivity networks. This digital infrastructure encompasses physical technology such as user devices, data centers and networks. However, it also relies heavily on access to spectrum to transport wireless communications, as well as electricity to power the infrastructure. The following discussion focuses on these intangible elements - spectrum and electricity - as it considers the implications for environmental taxation.

\subsection{Spectrum - an Environmental Resource Eligible for Environmental Pricing?}

The digital world cannot thrive without access to spectrum. "Spectrum" describes electromagnetic waves operating at various frequencies. Digital technology uses electromagnetic waves to deliver voice, text and video communications. ${ }^{4}$ While some data travel by other means, such as through cables, transmission through the air depends upon spectrum. Demands for spectrum are increasing as traffic moves to wireless and mobile devices. ${ }^{5}$ According to the International Energy Agency's (IEA) 2017 analysis, the number of mobile phone subscriptions exceeded the number of people on earth. ${ }^{6}$ Consumer markets drive demand for data-intensive transmission, in particular video, ${ }^{7}$ and projections suggest that $25-50$ billion Internet of Things devices will need spectrum access by $2025 .{ }^{8}$

From an environmental taxation perspective, key questions are whether spectrum should be regarded as an environmental asset and, if so, whether environmental pricing theories might apply. One can argue that spectrum is part of the environment because it is a limited natural resource in the commons. The US government and the European Parliamentary Research Service have characterized spectrum as a natural resource. ${ }^{9}$ 
This classification is consistent with the notion that spectrum is part of the physical, albeit invisible, atmosphere, not unlike oxygen or ozone. Spectrum is also a finite resource. As a Commissioner of the US Federal Communications Commission testified, "The iron laws of physics being what they are, we are simply not making more." 10 Therefore, government needs to use the resource efficiently ${ }^{11}$ and ensure that the supply of spectrum can meet growing demand. ${ }^{12}$ Access to spectrum may provoke a new generation of environmental justice issues - the justice of who has digital rights of access and on what terms. At the very least, we should consider what constitutes the "environment" for policy purposes and whether environmentalists should have a seat at the table when decisions are made about spectrum's use.

Treating spectrum as an environmental asset opens the door to thinking about how to price this limited natural resource. Governments can allow spectrum use for free by awarding licenses or leaving spectrum bands open to unlicensed use. Free allocation will yield private sector windfalls, but it can also recognize the need to accommodate everyday uses, such as in-home Wi-Fi. ${ }^{13}$ Environmental pricing might also play a role. A natural resource tax could allow governments to capture some portion of the economic rent associated with the private sector's use of spectrum. ${ }^{14}$ Alternatively, governments could treat rights to use spectrum as property that must be bought from the government or in the marketplace. In 1959, Ronald Coase advocated treating radio and television frequencies as property rights, allowing holders to negotiate to resolve conflicts that cause interference. ${ }^{15}$ (This work led to Coase's famous 1960 article, The Problem of Social Cost. ${ }^{16}$ ) Regardless of which pricing instrument governments might use, if any, spectrum represents a financially valuable resource. In the US, one auction for licensed wireless spectrum in 2015 grossed almost $\$ 45$ billion, ${ }^{17}$ and unlicensed spectrum was valued several years ago at more than $\$ 220$ billion. ${ }^{18}$ Revenue from spectrum allocation could fit neatly into theories of environmental fiscal reform. ${ }^{19}$ In short, environmental policy would hold a valuable asset.

Much has been written elsewhere about the merits of various approaches to allocating access to spectrum..$^{20}$ This chapter serves only as a signal that today's digital world can offer a new lens through which to view the meaning of "environment" and the role of environmental pricing.

\subsection{The Digital World's Electricity Consumption - the Continuing Need for Carbon Pricing}

ICT forms the essential, vast and ever-growing skeleton of the digital world - data centers that process and store data, networks that transmit the flow 
of data and connected end user devices from laptops to smart watches. Electricity powers this infrastructure. A report by Greenpeace estimated that the information technology sector, including manufacturing, could account for 12 percent of global electricity demand in 2017, up from 7 percent in 2012. ${ }^{21}$ According to the IEA, data centers consumed about 1 percent of global electricity and data networks accounted for another 1 percent. Projections about future energy consumption vary widely: data centers and networks could demand more energy, or advances in efficiency could curb growth in their energy consumption. ${ }^{22}$

The ostensible cleanness of the digital world, which often comes from its ethereal, remote nature, should not cloak its real carbon footprint. For example, Greenpeace maintains a clean energy index for companies that provide a variety of digitally based services. ${ }^{23}$ The scores range from highs of 100 percent for Switch and 83 percent for Apple to lows of 2 percent for almost 40 companies. These figures do not account for the electricity consumed by data networks or end users' devices. The carbon profile of that electricity depends on the extent to which local electricity providers rely on clean sources of energy.

The digital context accentuates the need to continue to press vigorously for meaningful prices on carbon dioxide emissions around the globe. Carbon taxes can motivate data centers to find clean sources of energy and encourage end users to focus on the amount and type of electricity their devices consume. Even if new digital applications can conserve energy, ${ }^{24}$ it is important to ensure that any benefits do not hide ICT's remaining carbon footprint. This emphasis on carbon pricing is not unique or creative. Using ICT's electricity consumption as just one example, it simply underscores the role of carbon pricing in shaping a clean, new economy.

\section{ONLINE RETAIL}

The digital world's infrastructure has spurred new lines of business. Online retail provides just one illustration of this consumer revolution. In Europe, online retail grew by 18 percent in 2015 and another 16 percent in $2016 .{ }^{25}$ In the US, online retail totaled $\$ 389$ billion in $2016 .{ }^{26}$ McKinsey has observed that technology will disrupt the consumer goods industry in the coming decade. ${ }^{27}$ The discussion below focuses on the role of environmental pricing in addressing two consequences of the online retail delivery system: packaging waste and the noise pollution that could arise with drone deliveries. 


\subsection{Transport Packaging Waste - Who and Where is the Polluter?}

As anecdotal evidence indicates, online retail delivers a mounting volume of packages and packaging waste to consumers. Amazon's 36-hour online Prime Day in 2018 generated sales of over 100 million products to consumers in 17 countries. ${ }^{28}$ In China, Alibaba's Singles' Day promotion for online buyers in 2017 shipped 331 million packages, up more than 31 percent from the prior year. These sales generate transport packaging waste that must be handled at the purchasers' end. China's 2017 Singles' Day sales alone generated an estimated 160000 tons of packaging waste. ${ }^{29}$

The rebound effect may contribute to increased levels of consumption and therefore transport packaging waste. The rebound effect is rooted in the notion that gains in energy efficiency may increase energy consumption, but it can apply to efficiencies outside of the energy sector. Analysts have called out the need to assess a range of rebound effects in the digital world ${ }^{30}$ Online retail and associated transport packaging provide a concrete context for considering rebound effects. As it becomes more efficient for consumers to order online, are people are consuming more and generating more packaging waste due to the rebound effect? ${ }^{31}$

Circular economy policy goals seek to avoid waste, reuse it or recycle it. ${ }^{32}$ In response to consumers' expressions of "wrap rage" 33 or guilt, ${ }^{34}$ online retail platforms may implement voluntary measures to reduce waste or enable recycling. ${ }^{35}$ Governments can also set standards. The European Union in 2018 set new minimum targets for Member States to recycle packaging waste, including 85 percent of cardboard by $2020 .{ }^{36}$ Fiscal measures can also play a role.

When considering pricing measures for transport packaging waste, fundamental policy questions are whose behavior needs to change and whether a government's tax arm can reach those players. Upstream online retailers make choices about packaging that affect waste downstream, but they are a diffuse group of "polluters" who can be difficult to locate. Online retail platforms may execute sales and shipping arrangements directly or facilitate sales for third parties that ship the goods. For example, Amazon handles approximately half of its sales directly and third-party sellers ship the rest of its orders; eBay operates entirely through third-party sellers. ${ }^{37}$ The increasingly international nature of online retail further complicates the ability to influence upstream behavior. Recent surveys of online purchasers in numerous regions of the world found that about half or more purchased outside their own country. ${ }^{38}$ Yet governments in the country of destination may have limited legal ability to impose a packaging tax on international shippers beyond their jurisdiction. ${ }^{39}$ Governments in both the country of origin and the 
country of destination need to grapple with the question whether there are ways to influence upstream behavior.

Alternatively, governments in destination countries can focus on downstream consumers. By generating demand for transport packaging, consumers are "polluters". If rebound effects prove real, consumer choices become especially critical. Pricing instruments can directly target consumers by imposing taxes or fees on packaging waste, sensitizing them to the waste associated with their purchases. ${ }^{40}$ If the revenue finances local waste treatment, this approach also can shift the cost of waste disposal from local taxpayers or ratepayers to people contributing the waste, drawing on the theory of user fees rather than environmental taxes. ${ }^{41}$

Transportation packaging waste adds urgency, cost, an international dimension and complex new consumer dynamics to the field of waste regulation, already a knotty problem. Still, the polluter pays principle should guide governments, which need to look both upstream and downstream for effective policies within their reach.

\subsection{Drones: Noise Taxes or Regulation?}

Then there is the matter of how online retail packages reach one's doorstep. The prospect of drone delivery is quickly becoming real. ${ }^{42} \mathrm{McKinsey}$ projected two years ago that within ten years, drones or autonomous vehicles in developed countries will handle 80 percent of parcel delivery for the proverbial last mile. ${ }^{43}$ If used, drones will lift traffic from the streets up into the air. This shift will alter the energy demands of package delivery in still-speculative ways, ${ }^{44}$ but drones also generate noise. Studies are starting to assess the degree of annoyance that drone noise generates under various conditions. $^{45}$ Noise as an externality puts in sharp focus the choice-ofinstrument question. Should government use a pricing instrument or regulation to address noise?

Noise taxes to date have been characterized as "symbolic in practice". 46 Some governments have imposed taxes on aviation noise to help finance mitigation measures around airports. ${ }^{47}$ However, drones' pervasiveness, lowflight levels and unaccustomed sound in urban and rural landscapes could ignite a more vigorous discussion of the role of noise taxes. It is important nonetheless to consider whether regulation is better suited to reduce drone noise. Regulation can set noise standards ${ }^{48}$ and local land use regulations can influence the location of drone delivery hubs to minimize impacts.

Choice-of-instrument considerations also involve identifying the appropriate level of government with legal power to act, analysis that will vary by country. ${ }^{49}$ As a matter of policy, technical design regulation seems better suited to the national level and land-use siting issues more appropriate for 
local authorities. Tax policies could fall into either domain. Taxes intended to steer design specifications would fit more logically with national taxes. Taxes intended to compensate for specific local externalities could be local in nature.

As a new form of pollution, drone noise presents a fresh opportunity to explore the relationship between regulatory and fiscal policies. Regulation is the right answer if noise pollution at any given level is not an acceptable externality. But if drone regulation would still allow some level of harmful noise pollution due to design limitations or lack of regulatory will, taxes might step in.

\section{URBAN CONGESTION}

The burgeoning digital economy creates new demands on the urban landscape and transportation systems. This section considers two urban developments that flow directly from the digital economy: large, new urban office complexes that house companies that drive the digital economy; and new transportation systems that operate on digital platforms. Both give rise to the question of whether governments should consider imposing a charge on activities that previously did not lie in the domain of traditional environmental taxation.

\subsection{Major Urban Employers - a New Tax Base?}

The US stands as a bellwether for considering the influence of large high-tech companies on the metropolitan environment. Tech companies have built major campuses in suburban and urban areas, such as Apple's and Google's headquarters in Silicon Valley, Microsoft's campus outside Seattle, and Amazon's headquarters in downtown Seattle, Washington. Not bound by the traditional infrastructure or natural resource requirements of many "old" industries, tech companies have flexibility to choose locations and employees often want to live or work in cities. ${ }^{50}$ And some states compete for their attention. Almost 240 cities responded when Amazon solicited proposals for supplemental headquarters in 2017. New York and Virginia, winning jurisdictions, offered more than $\$ 2$ billion in tax incentives to attract 50000 new jobs. ${ }^{51}$

Tech companies can stimulate the local economy, but they can also contribute to traffic congestion and rising costs of housing. The lack of affordable housing in turn can cause people to move further away from their jobs, increasing concerns about environmental justice and carbon footprints. In Seattle, home prices in 2017 rose twice as fast as the next 
city in the ranking of rising house values. ${ }^{52}$ In San Francisco, the median home price in mid-2018 was $\$ 1.6$ million..$^{53}$ In response, several cities have explored taxing employers based on the number of employees to provide funding for transportation and housing needs. These proposals show how environmental pricing might apply to a new kind of tax base - number of employees. Thus, even while some governments offer tax incentives to attract companies, others are seeking ways to shift the cost of negative externalities to companies already on site.

In Mountain View, California, home of Google's headquarters, voters approved a per-employee tax in $2018 .{ }^{54}$ At the top end of the progressive tax rate, companies with more than 5000 employees will pay $\$ 150$ per employee over that threshold. ${ }^{55}$ Google, which employs 23000 people in the city, ${ }^{56}$ will pay about half of the projected $\$ 6$ million annual revenue. Revenue will go into the general fund, but can be used to address traffic congestion, bicycle and pedestrian routes, and affordable housing. ${ }^{57}$ Cupertino, California, headquarters of Apple, considered a per-employee tax on companies with more than 99 employees in the city, but deferred putting the issue to voters until $2020 .{ }^{58}$ The city would have used the revenue, an estimated $\$ 10$ million per year, to address traffic issues. ${ }^{59}$

In Seattle, home of Starbucks, Amazon and other tech companies, a measure was enacted, then repealed. In May 2018, the City Council imposed tax of $\$ 275$ per employee on companies with revenue of more than $\$ 20$ million, which would have generated $\$ 50$ million per year for affordable housing. The City Council's decision spurred an organized effort to put repeal of the tax on the ballot for voters in November 2018 ("No Tax on Jobs"), ${ }^{60}$ supported by Amazon, Starbucks and others. In June 2018, the City Council repealed the tax. ${ }^{61}$ In January 2019, Microsoft, headquartered just outside Seattle, voluntarily pledged $\$ 500$ million to address affordable housing in the region. ${ }^{62}$

From a traditional environmental policy perspective, placing the cost of responding to transportation and housing needs on employers has merit. Employees create externalities by engaging directly in transportation and housing markets, but employers' expansion strategies are the underlying force behind these externalities. There are, of course, other ways that government might address transportation and housing externalities, such as by amending land use regulations, imposing one-time impact fees or exactions at the time of construction, or considering Henry George's theory land value taxation. ${ }^{63}$ However, the point here is quite simple. The digital world has created major new economic players that can herald a significant shift in urban patterns. It is time to consider new tax bases that would not have been considered "environmentally related" under traditional twentieth century definitions. ${ }^{64}$ 


\subsection{Curbside Congestion - Fees and New Horizons for Administratively Feasible Tax Bases?}

The digital world has created innovative, alternative means of transportation, but those alternatives bring their own style of urban congestion. Private transit options built on digital platforms take many forms. They provide transportation by bus, van, car, bicycle or scooter. They may involve single-use services on a hired basis, such as UberX or bicycle rentals; or they may offer shared transportation, such as Uber Pool, BlaBlaCar and "dollar vans" ${ }^{65}$ Employer-operated buses, such as the "tech buses" in Silicon Valley, are not exclusive to the digital economy, but major digital employers have accentuated their visibility.

The focus here is not on whether these services yield a net positive or negative impact on greenhouse gas emissions, ${ }^{66}$ but instead whether environmental pricing might play a role in addressing new forms of congestion at the curbside. Ride-hailing services need to pull over to pick up customers at digitally arranged points. Sidewalk bike stations service users and "dockless" bike systems allow riders to pick up and leave bikes anywhere on the sidewalk. Increased bike and electric scooter usage contributes to traffic at the road's edge and generates calls for protected bike lanes. There is now competition for the curbside, long considered a relatively passive public asset. ${ }^{67}$

Some local governments are regulating these adverse effects. In 2018, New York City adopted a one-year ban on issuing new licenses to for-hire cars to gain time to consider how to respond to congestion. ${ }^{68}$ Before companies such as Uber entered the market, New York City allowed 13637 taxicab licenses. ${ }^{69}$ In 2018, there were over 100000 for-hire vehicles on the city's streets. ${ }^{70}$ Beverly Hills, California, temporarily banned the use of shared electric scooters in 2018. ${ }^{71}$

Jurisdictions are looking at pricing options as well. When corporate tech buses used municipal bus stops and pullovers that blocked travel or bike lanes, San Francisco responded by negotiating designated stops and administrative fees for each stop. ${ }^{72}$ When for-hire electric bikes and scooters in Santa Monica, California, generated concerns about safety and sidewalk and bike path congestion, ${ }^{73}$ the city instituted a pilot program. It awarded licenses to four companies to initially operate up to a total of 2000 e-scooters and 1000 e-bikes ${ }^{74}$ and required them to pay an annual fee of $\$ 20000$ and $\$ 130$ for each device in the system to cover the city's cost of operating the program..$^{75}$ These fees do not capture the cost of externalities, but under classic fee theory, they move the cost of government administration to the beneficiaries.

These new activities can also lead costly investments in public improvements. For example, a US study estimates that the cost of constructing 
protected bike lanes can range from about $\$ 500000$ to $\$ 4.3$ million per mile. ${ }^{76}$ The environmental pricing question is who should pay for public investments in alternative transit: the public that may benefit from reduced pollution or the companies that benefit from using public spaces. If financing for bike and pedestrian measures is a relatively low public priority, a tax or fee can be particularly appealing. ${ }^{77}$ Santa Monica's program for e-scooters and e-bikes took a step in this direction. It charges a $\$ 1$ public right-of-way fee per device per day to fund infrastructure improvements. ${ }^{78}$

The shared transportation community may be open to considering fees. Bird, a dockless e-scooter company, has indicated that it intends to create a fund to help build or maintain bike paths in cities where it operates, financed by $\$ 1$ per day per scooter. ${ }^{79}$ In 2018 , a group of companies and organizations around the world signed onto a statement of shared mobility principles that includes a pricing principle: "Every vehicle and mode should pay their fair share for road use, congestion, pollution, and use of curb space. The fair share shall take the operating, maintenance and social costs into account." 80 Over 30 service providers signed on. This principle represents a significant step toward acknowledging pricing as a path forward for shared and other vehicles.

The International Transport Forum, representing 59 countries, went a step further. It has suggested the possibility of "curb-kiss" fees that could help manage traffic and demand for curb access. This option would require the development of new digital infrastructure that would count curb kisses. It could allow for fees that vary depending on time of day, location and type of access. ${ }^{81}$ This idea presents an intriguing concept that shows how environmental taxes could reach a new tax base as a result of the digital economy - and how digital technology could make that new tax base administratively feasible. Fiscal policy at the curbs of the future may run the gamut from traditional fees to new tax innovations.

\section{DIGITAL PAYMENT - THE NEED TO REVISIT TAX RATE THEORY AND PRACTICE?}

Finally, one last inquiry of a more theoretical nature: the effect of digital wallets on the salience of environmental taxes. Does the ease of digital payment make consumers less aware of tax burdens and, therefore, less likely to take tax signals into account in their decision-making? If so, environmental tax rates may need to increase to preserve their behavioral signal.

Forms of payment have shifted over decades from cash to credit cards, and now to digital money and digital wallets. Digital money has been 
described as value transferred through the digital environment that is backed by cash or a credit card account. ${ }^{82}$ Digital wallets, such as PayPal, facilitate these transactions, ${ }^{83}$ as do apps on mobile phones. According to a 2016 report, 46 percent of US consumers used mobile payment. ${ }^{84}$ Studies have found that payment by credit card increases consumer consumption because it reduces the pain of payment by cash. ${ }^{85}$ Although research on the effect of digital payment is still in its early phases, at least one study posits that digital money has the same effect on consumer purchasing as credit cards. ${ }^{86}$ As one academic noted in the popular press, "The less friction there is, the easier it becomes to spend ... Just stand at Starbucks and watch how many people there use their smartphones to buy a latte." 87 Similarly, digital payment may diminish the pain of a tax. A study of highway tolls suggested that the lower salience of electronic collection of tolls allowed government to impose higher toll rates and that elasticity in driving patterns declined in the short run. 88

If digital payment erodes the salience of environmental taxes, it will be important to revisit the theories underlying environmental tax rates. Under Pigouvian theory, the tax rate should reflect the social cost of negative externalities. ${ }^{89}$ However, if the form of payment distorts the rational decision-making that Pigou assumed, the tax rate calculation should be adjusted upward for the "deflation" that might come with digital payment. This would result in an externality-plus tax rate. Under the Baumol-Oates theory of environmental taxation, the tax rate should be set at the level required to reach the desired degree of behavioral change. ${ }^{90}$ Therefore, the calculation of a Baumol-Oates tax rate should take into account the behavioral impact of the manner of payment, building in an anti-deflation factor if necessary. Hence, adapting Pigouvian theory to the digital world may require an adjustment in tax rate theory; setting a tax rate under the Baumol-Oates approach only requires an adjustment in how theory is applied.

\section{CONCLUSION}

This exploration has delved into just a few pockets of the emerging digital world, but it yields several thoughts that may have broader applicability as policies surrounding the Digital Revolution develop. At a fundamental level, the evolution of the digital world should press us to reevaluate how we define the environment. This chapter suggests that the boundaries of the environment could encompass the capacity of the atmosphere to transport the data - the invisible digital highways of spectrum without which the digital world cannot flourish. 
Environmental pricing principles should be built into the foundation of the digital world during its relative infancy, not added as a cornice later. The Digital Revolution reinforces the need to continue to apply traditional environmental pricing approaches, such as carbon taxes, to address negative environmental consequences. It also creates new tax bases that demand attention. The inquiry into new taxes, however, requires careful thought about whether environmental goals are best served through pricing measures, regulation or an artful combination. As an enduring principle, environmental taxation is a means to an end, not an end in itself.

The emerging digital world may accentuate the need to consider environmental user fees. Environmental fees sometimes seem rather like environmental taxation's intellectually neglected sibling. Environmental taxes grew from sophisticated economic theories, while environmental fees developed from pragmatic desires to pay for services and often garner less theoretical attention. Yet fees can provide important sources of revenue that governments need to address new demands of the digital economy.

The medium of digital technology can influence the tax base and rate. Digital technology may allow governments to identify and tax activities that previously would have been infeasible. At the same time, new technology may disrupt traditional environmental taxation theory and practice by altering how people pay taxes. Economists, behavioral economists, environmentalists and policymakers need to reconsider assumptions about how to set tax rates.

Finally, perhaps even this preliminary and partial exploration of the intersection of the digital world and environmental pricing can invite others to think about new frontiers for fiscal environmental policies at global, national, and local levels. The digital world knows no national boundaries; nor should the theory and practice of environmental taxation and environmental fees.

\section{NOTES}

* The author thanks Emma Akrawi for her invaluable research and editorial suggestions.

1. International Energy Agency [IEA], Digitization \& Energy 22 (2017).

2. Daniel Z. Sui and David W. Rejeski, Environmental Impacts of the Emerging Digital Economy: The E-for-Environment E-Commerce? 29 Envtl. Mgmt, no. 2, 2002, 155, 159.

3. See Klaus Fichter, E-Commerce: Sorting Out the Environmental Consequences, 6 J. Indus. Ecology, no. 2, 2003, 25, 27.

4. See Congressional Research Service, Spectrum Policy: Provisions in the 2012 Spectrum Act 1 (2015); European Parliamentary Research Service [EPRS], Radio Spectrum 1 (2015).

5. IEA, supra note 1 , at 109.

6. Id. at 15 . 
7. U.S. Government Accountability Office [GAO], Internet of Things: FCC Should Track Growth to Ensure Sufficient Spectrum Remains Available 17 n. 25, 18 (2017).

8. Id. at 1 .

9. Id. at 4; EPRS, supra note 4, at 1. But see Milton Mueller, Cato Institute Policy Analysis No. 11: Property Rights in Radio Communication (1982).

10. Wireless Broadband and the Future of Spectrum Policy, Hearing before the Committee on Commerce, Science, and Transportation, US Senate (2015) (Prepared Statement of Hon. Jessica Rosenworcel, Commissioner, Federal Communications Commission at 6).

11. Robert Matheson and Adele C. Morris, The Technical Basis for Spectrum Rights: Policy to Enhance Market Efficiency 10-11, 17-19 (2011).

12. See Dorothy Robyn, Making Waves: Alternative Paths to Flexible Use Spectrum 1 (2015); GAO, supra note 7.

13. Hearing on Exploring the Value of Spectrum to the U.S. Economy, U.S. Senate Committee on Commerce, Science, and Transportation, Subcommittee on Communications, Technology, Innovation and the Internet (2017) (statement of Dave Heiner, V.P., Regulatory Affairs, Microsoft Corporation).

14. For discussions of natural resources taxes, see Organisation for Economic Co-operation and Development [OECD] Task Force for the Implementation of the Environmental Action Program for Central and Eastern Europe, The Use of Economic Instruments for Pollution Control and Natural Resource Management in EECCA 51 (2003); H. William Batt, Taxing Land Rents for Urban Liability and Sustainability, in Environmental Taxation and Climate Change 103-106 (L. Kreiser et al. eds., 2011). A Pigouvian tax that captures the social cost of frequency interference would not seem appropriate if some level of continuing interference would not serve the public interest.

15. R.H. Coase, The Federal Communications Commission, II J.L. \& Econ. 1 (1959).

16. R.H. Coase, The Problem of Social Cost, III J.L. \& Econ.1, n.1 (1960).

17. Linda K. Moore, Congressional Research Service, Framing Spectrum Policy: Legislative Initiatives 5 (2016).

18. Doug Brake, Coase and WiFi: The Law and Economics of Unlicensed Spectrum 3 (Information Technology \& Innovation Foundation, 2015).

19. See generally Jean-Philippe Barde and Olivier Godard, Economic Principles of Environmental Fiscal Reform in Handbook of Research on Environmental Taxation (J. Milne and M.S. Andersen eds., 2010) 33-58.

20. See, e.g., Moore, supra note 17; Robyn, supra note 12; Suzan Bayhan et al., The Future is Unlicensed: Coexistence in the Unlicensed Spectrum for 5G (2018).

21. Gary Cook, Clicking Clean: Who Is Winning the Race to Build a Green Internet? 15 (2017).

22. IEA, supra note 1, at 103 .

23. Cook, supra note 21, at 8-13 (2017).

24. See IEA, supra note 1, at 16-18; Policy Connect, Is Staying Online Costing the Earth? (2018); Jonathan G. Koomey, H. Scott Matthews and Eric Williams, Smart Everything: Will Intelligent Systems Reduce Resource Use? 38 Ann. Rev. Envtl. Resources 311 (2013).

25. European Environment Agency, Circular by Design: Products in the Circular Economy 19 (2017).

26. US Census Bureau, E-Stats 2016: Measuring the Electronic Economy 2 (2018).

27. Ishan Chatterjee et al., McKinsey \& Co., The Decade Ahead: Trends that Will Shape the Consumer Goods Industry 10 (2010).

28. Press Release, Amazon, Prime Members Again Enjoyed the Biggest Global Shopping Event in Amazon History this Prime Day (July 18, 2018).

29. Reuters, China Faces 160,000 Tonnes of Packaging Waste after Singles' Day Buying Binge, The Straits Times, Nov. 17, 2017.

30. See Cedric Gossart, Rebound Effects and ICT: A Review of the Literature, in ICT Innovations for Sustainability 435 (M.L. Hilty and B. Aebischer eds., 2015); Tilman Santarius, Digitization, Efficiency and the Rebound Effect (2017), www.degrowth. infoen/2017/02/digitizatoin-efficiency-and-the-rebound-effect/. 
31. See, e.g., Sui and Rejeski, supra note 1, 155, 157 (impact of online book purchase).

32. See generally Conrad B. MacKerron, Waste and Opportunity 2015: Environmental Progress and Challenges in Food, Beverage and Consumer Goods Packaging (2015); European Environment Agency, Waste Prevention in Europe - the Status in 2014 (2015).

33. Olivia Gagan, E-Tailers Must Wrap Up a Better Package, Raconteur, Sept. 21, 2017.

34. Matt Richtel, E-Commerce: Convenience Built on a Mountain of Cardboard, NY Times, Feb. 16, 2016.

35. Amazon, Frustration-free packaging, www.aboutamazon.com/sustainability/packaging/ frustration-free-packaging.

36. Directive of the European Parliament and of the Council Amending Directive 94/62/EC on Packaging and Packaging Waste, May 30, 2018, Art. 1(6).

37. OECD, Extended Producer Responsibility (EPR) and the Impact of Online Sales 31 (2018).

38. PayPal, PayPal Cross-Border Consumer Research 2018: Global Summary Report 7 (2018); UPS, UPS Impulse of the Online Shopper ${ }^{\mathrm{TM}}$ Study: Global Study, Executive Summary 9 (2018).

39. $C f$. OECD, supra note 37 , at 6, 25-33 (risk of free-riding for international online sales in extended producer responsibility context).

40. $C f$. Institute for European Environmental Policy, Capacity Building for Environmental Tax Reform 44-60 (2017) (discussing existing pay-as-you-throw fees).

41. See OECD, Environmentally Related Taxes in OECD Countries 15 (2001) (distinguishing environmental taxes and fees).

42. See, e.g., Arthur Holland Michel, Amazon's Drone Patents 1 (2017); Alan Levin, Toddler's Popsicle-by-Air Marks First in US Drone Delivery, Bloomberg, Aug. 8, 2018, www.bloom berg.com/news/articles/2018-08-08/toddler-s-popsicle-by-air-marks-milestone-in-u-sdro ne-delivery. Regulation of commercial delivery drones varies significantly by country. See Therese Jones, Rand Corp., International Commercial Drone Regulation and Drone Delivery Service iii (2017).

43. Martin Joerss et al., McKinsey \& Co., Parcel Delivery: The Future of Last Mile 7 (2016). See also Jones, supra note 42, at iii.

44. See Joshuah K. Stolaroff et al., Energy Use and Life Cycle Greenhouse Gas Emissions of Drones for Commercial Package Delivery, 9 Nature Comm. 409 (2018); Miguel Figliozzi, Drones for Commercial Last-Mile Deliveries: A Discussion of Logistical, Environmental and Economic Tradeoffs (Civil and Environmental Engineering Faculty Publications and Presentations 416, 2017); Andrew J. Lohn, Rand Corp., What's the Buzz? The CityScale Impacts of Drone Delivery (2017); Timothy R. Gulden, Rand Corp., The Energy Implications of Drones for Package Delivery: A Geographic Information System Comparison 10 (2017).

45. Lohn, supra note 44, at 20; Andrew Christian and Randolph Cabell, Initial Investigation into the Psychoacoustic Properties of Small Unmanned Aerial System Noise 18-20 (2018).

46. Marta Villar Ezcurra, Noise Pollution Taxes: A Possibility to Explore, in Innovation Addressing Climate Change Challenges: Market-based Perspectives 113, 119 (M. Hymel et al. eds., 2018).

47. See Code General des Impots [Internal Revenue Code] art. 1609 quatervicies A (Fr.); Aircraft Noise Levy Act 1995 (Austrl.); Aircraft Noise Levy Collection Amendment Bill 2001 (Austrl.).

48. See Regulation (EU) 2018/1139 of the European Parliament and the Council of 4 July 2018, 2018 O.J. (L 212) 1.

49. See, e.g., Singer v. City of Newton, 284 F. Supp. 3d 125 (D. Mass. 2017); Regulation (EU) 2018/1139, supra note 48.

50. Nellie Bowles, San Francisco Measure Targets a Tech Staple: The Free Lunch, NY Times, Aug. 1, 2018, B1.

51. L. David Goodman, In New York and Virginia, Amazon Is Sold on a Deal, NY Times, 
Nov. 14, 2018, A.1. Amazon subsequently withdrew its plans to locate a headquarters in New York in response to local opposition.

52. Kirk Johnson, Lessons Seattle Can Teach Other Cities About Amazon, NY Times, Nov. 17, 2017, A13.

53. Kevin Kelleher, San Francisco's Home Prices Soared an Average of \$205,000 in Past 6 Months, Fortune, July 6, 2018.

54. Mark Noack, Twin MV Tax Measures Coast to Victor, Mountain View Voice, Nov. 7, 2018.

55. Id. City of Mountain View, Proposed Ordinance, www.mountainview.gov/civicax/ filebank/blobdload.aspx?BlobID=27111.

56. Marlize van Romburgh, Mountain View Mulls Taxing Large Employers Like Google Millions, Silicon Valley Bus. J., May 9, 2018.

57. City of Mountain View, Business License Tax Measure P, Ballot Measure, https://www. mountainview.gov/depts/manager/2018_potential_general_revenue_measures.aspl; City of Mountain View, Impartial Analysis, www.mountainview.gov/civicax/filebank/blobd load.aspx?BlobID=27115; Natasha Mascarenhas, Google Tax to Go Before Voters as Tech Giant's Hometown Puts Proposal on Ballot, San Francisco Chronicle, June 26, 2018.

58. Khalida Sarwari, Cupertino Shelves Proposed 'Head Tax' on Apple Employees for Now, Mercury News, July 31, 2018.

59. Id.

60. http://notaxonjobs.com/.

61. David Streitfeld and Claire Ballentine, Amazon Played Hardball on New Tax. Now Seattle is Killing the Tax, NY Times, June 13, 2018, at B1.

62. Karen Weise, Microsoft Pledges $\$ 500$ Million to Ease Seattle Housing Crisis, NY Times, Jan. 17, 2019, at A1.

63. See generally Richard F. Dye and Richard W. England, Assessing the Theory and Practice of Land Value Taxation (2010); Planning Committee, London Assembly, Tax Trial. A Land Value Tax for London? Feb. 2016; Letter from Sadiq Khan, Mayor of London, to Tom Copley, City Hall, Nov. 2, 2016.

64. See, e.g., OECD, Environmentally Related Taxes in OECD Countries 15 (2001); Eurostat, Environmental Taxes: A Statistical Guide 9 (2001).

65. See generally Saron Feigon et al., Private Transit: Existing Services and Emerging Directions, Transit Cooperative Research Program (2018); Shared-Use Mobility Center, Shared-Use Mobility: Reference Guide (2015).

66. See, e.g., Feigon et al., supra note 65, at 25-26; Nordic Council of Ministers, Environmental Impacts and Potential of the Sharing Economy 47-57 (2017); SharedUse Mobility Center, supra note 65, at 14-15.

67. See generally International Transport Forum, The Shared-Use City: Managing the Curb (2018).

68. Press Release, Office of the Mayor, Mayor de Blasio, Signs for-Hire Vehicle Legislation (Aug. 14, 2018).

69. Emily Badger, What's the Right Number of Taxis? NY Times, Aug. 11, 2018, B1.

70. Emma G. Fitzsimmons and William Neuman, This Time It's Uber's Turn to Wage an Uphill Battle, NY Times, July 28, 2018, at A15.

71. Press Release, City of Beverly Hills, Beverly Hills to Prohibit the Use of Motorized Scooters for Six Months (July 24, 2018).

72. Feigon, supra note 65, at 32-36.

73. City of Santa Monica, Staff Report 3006 (2018).

74. Ordinance No. 2578 (June 26, 2018); City of Santa Monica Shared Mobility Device Pilot Program Administrative Regulations (Sept. 25, 2018); City of Santa Monica, David Martin, Final Administrative Decision (Aug. 30, 2018).

75. Santa Monica Administrative Regulations, supra note 74, §3.5; City of Santa Monica, Staff Report 3006 (2018); City of Santa Monica, Frequently Asked Questions About the Shared Mobility Pilot Program (2018). 
76. Max A. Bushell et al., Costs for Pedestrian and Bicyclist Infrastructure Improvements $12(2013)$.

77. U.S. Government Accountability Office, Pedestrians and Cyclists: Cities, States and DOT Are Implementing Actions to Improve Safety 23 (2015).

78. David Martin, City of Santa Monica, City Council Report (Aug. 28, 2018); City of Santa Monica, Frequently Asked Questions About the Shared Mobility Pilot Program (2018).

79. Bird, Save Our Sidewalks Pledge, March 27, 2018, www.bird.co/sos-pledge-mar272018.

80. Shared Mobility Principles for Livable Cities, Principle 7, www.sharedmobilityprinci ples.org.

81. International Transport Forum, supra note 67, at 35, 80-81.

82. See Farah Diba Abrantes Braga, Giuliana Isabella and José Afonso Mazzon, Do Digital Wallets as Payment Method Influence Consumer in Their Buying Behavior? XXXVII Encontro de ANPAD 4 (2013).

83. Id. at 5 .

84. Pew Charitable Trusts, Who Uses Mobile Payments? Survey Findings on Consumer Opinions, Experiences 1, 3 (2016).

85. See Braga et al., supra note 82; Drazen Prelec and Duncan Simester, Always Leave Home Without It: A Further Investigation of the Credit-Card Effect on Willingness to Pay, 21 Marketing Letters 21:1, 5-12 (2001); Manoj Thomas, Kalpesh Kaushik Desai and Satheeshkumar Seenivasan, How Credit Card Payments Increase Unhealthy Food Purchases: Visceral Regulation of Vices, 38 J. Consumer Research (2011); Priya Raghubir and Joydeep Sirvastava, Monopoly Money: The Effect of Payment Coupling and Form on Spending Behavior, 14 J. Experimental Psychology: Applied, no. 3, 213 (2008); Greg B. Davies, The Realities of Spending, 2 Argent, no. 6, 22 (2003).

86. Braga et al., supra note 82 .

87. Nelson D. Schwartz, Credit Cards Encourage Extra Spending as the Cash Habit Fades Away, NY Times, March 25, 2016 (quoting Richard Feinberg, Purdue University).

88. Amy Finkelstein, E-ZTax: Tax Salience and Tax Rates (Nat'l Bureau of Econ. Research, Working Paper No. 12924, 2007).

89. A.C. Pigou, The Economics of Welfare 168 (1920).

90. William J. Baumol and Wallace E. Oates, The Use of Standards and Practices for Protection of the Environment, 73 Swedish J. Econ. no. 1, 1971, 42-54. 